\title{
水素・空気乱流予混合火炎における火炎近傍の歪み速度特性 Characteristics of Strain Rates near Flame Front in Turbulent Hydrogen-Air Premixed Flames
}

\author{
○源 勇気（東工大院） 正 名田 譲（豊橋技科大） \\ 正 店橋 護（東工大院） 正 宮内 敏雄（東工大院）
}

Yuki Minamoto, Tokyo Institute of Technology, Ookayama, Meguro-ku, Tokyo

Yuzuru Nada, Toyohashi University of Technology, Hibarigaoka, Tempaku, Toyohashi, Aichi

Mamoru Tanahashi, Tokyo Institute of Technology, Ookayama, Meguro-ku, Tokyo

Toshio Miyauchi, Tokyo Institute of Technology, Ookayama, Meguro-ku, Tokyo

\begin{abstract}
Three-dimensional direct numerical simulations (DNS) with detailed kinetic mechanism have been conducted for statistically-planar, freely-propagating turbulent flame and turbulent V-flame of hydrogen-air mixture in relatively high Reynolds number turbulence. DNS of each configuration was performed in two numerical conditions which are characterized by the difference of Reynolds number. From these results, eigen values of strain tensor are evaluated to investigate characteristics of the strain field near the flame and alignment of the principal strain and flame. Strong dependency of turbulent-flame interaction on Reynolds number and convection are revealed. Interesting feature of high Reynolds number turbulent flame is described as well.
\end{abstract}

Key Words: 3D DNS, Turbulent Combustion, V-Flame, Principal Strain Rates

\section{1. 諸論}

乱流燃焼モデルは燃焼器内の CFD 解析の精度に大きな 影響を与える。近年，より高精度な乱流燃焼モデルを構築 するために様々な方法が提案されている，通常，開発され たモデルの検証は数值的方法と実験的方法により行われて いる. 詳細化学反応機構を用いた直接数値計算 (DNS) は 最も高精度な計算手法であるが，その一方で膨大な計算資 源を必要とする.そのため, 多くは二次元 DNS にとどまっ ている.しかし，乱流運動は本質的に三次元であり，乱流 火炎の局所構造に大きな影響を与える歪み速度の固有值は 平均的に 2 つ正值と 1 つの負值を有しているため, これ らの性質を二次元 DNS で表現することはできない.

一方，実験的手法では，Stereoscopic PIVとPLIF を用い た複合レーザ計測(1)により乱流火炎の様々な情報を得るこ とができるようになった。しかし，これらの手法を用いて も得られるデータは二次元断面内に留まっており，モデル の検証にはこれらの二次元データが用いられている(2,3).

本研究では, 詳細化学反忘機構を考慮に入れた三次元 DNS 統計的に平面な水素・空気乱流予混合火炎と $\mathrm{V}$ 型水 素・空気乱流予混合火炎に対して行った。さらに，DNS 結 果から歪み速度テンソルの固有值及び固有ベクトルを算出 し, 高 Reynolds 数乱流及び対流が乱流火炎の動的特性に及 ぼす影響を明らかにした。

\section{2. 水素・空気乱流予混合火炎の DNS}

平面乱流予混合火炎の DNS には, 以前の研究と同様な基 礎方程式及び計算方法を用いた ${ }^{(4)}$. 計算は圧力 $0.1[\mathrm{MPa}]$, 当量比 $\phi=1.0$, 予熱温度 $700[\mathrm{~K}]$ の条件を対象とした。平面 乱流予混合火炎の DNS では 2 つの異なる Reynolds 数 $\left(R e_{\lambda}=60.8\right.$ 及び 97.1) に対して DNS を行った. ここで, Re $e_{\lambda}$ は Taylor microscale $(\lambda)$ 基づく Reynolds 数である. 表 1

Table 1 Numerical conditions

\begin{tabular}{c|c|c|c|c|c}
\hline \hline & $R e_{\lambda}$ & $N_{x} \times N_{y} \times N_{z}$ & $L_{x} \times L_{y} \times L_{z}[\mathrm{~mm}]$ & $u^{\prime} / S_{L}$ & $l / \delta_{F}$ \\
\hline \hline \multirow{2}{*}{ Planary } & 60.8 & $513 \times 128 \times 128$ & $10 \times 5 \times 5$ & 3.39 & 89.8 \\
\cline { 2 - 6 } & 97.1 & $1025 \times 384 \times 384$ & $7.4 \times 7.4 \times 7.4$ & 5.78 & 122 \\
\hline \hline \multirow{2}{*}{ V-flame } & 60.8 & $513 \times 257 \times 257$ & $10 \times 5 \times 5$ & 3.39 & 89.8 \\
\cline { 2 - 6 } & 97.1 & $769 \times 385 \times 385$ & $10 \times 5 \times 5$ & 8.47 & 83.3 \\
\hline
\end{tabular}

に平面乱流予混合火炎の計算条件を示す。ここで, $u^{\prime}, S_{L}$, $l$ 及び $\delta_{F}$ はそれぞれ乱流強度, 層流燃焼速度, 積分長及び 層流火炎厚さである。これらの計算結果から得られた反忘 進行変数 $(c=0.30)$ の等值面を図 1 に示す.これらの絬果は 異なる Reynolds 数での火炎構造の特徵走示している ${ }^{(5)}$.

図 2 に 型乱流予混合火炎の DNS の模式図を示す。V 型火炎の DNS では, 前述の平面乱流火炎の場合と同様な支 配方程式を用いたが，全方向に 4 次精度中心差分法を用い て離散化した. 境界条件として, $x$ 方向と $y$ 方向には NSCBC, $z$ 方向には周期境界条件を用いた、 $\mathrm{V}$ 型火炎の計算条件も 表 1 に示した。予混合気は压力 0.1 [MPa], 当量比 $\phi=1.0$, 予熱温度は700 [K] とした. 初期条件として最大温度が 2000 $[\mathrm{K}]$ のガウス分布型の温度分布をロッドの位置に与えるこ とで着火させた後, ロッド表面の温度を 2000 [K] に保持し, 火炎を維持させた。ただし，ロッド表面の流体速度はゼロ とし, 組成は既然ガスとした。

流入速度を $u_{i n}(y, z, t)=U_{c}+u^{\prime}(y, z, t)$ と与えた。ここで， $U_{c}$ は平均流入速度, $u^{\prime}(y, z, t)$ は速度变動を示している. 本 研究では, 速度変動としてスペクトル法を用いたDNSから 得られた十分発達した一様等方性乱流の速度場を与えた ${ }^{(6)}$. ここで, 各時刻の流入速度変動は, フーリエ空閒内で位相 をシフトさせることにより綮密に与えた。また， $U_{c}$ は平面 乱流火炎の DNS では火炎面が計算領域の中央部に位置す るように, V 型乱流火炎の DNS では $R e_{\lambda}=60.8$ 及び 97.1 で それぞれ $10 S_{L}$ 及び $20 S_{L}$ とした。 図 3 と図 4 は統計的に定
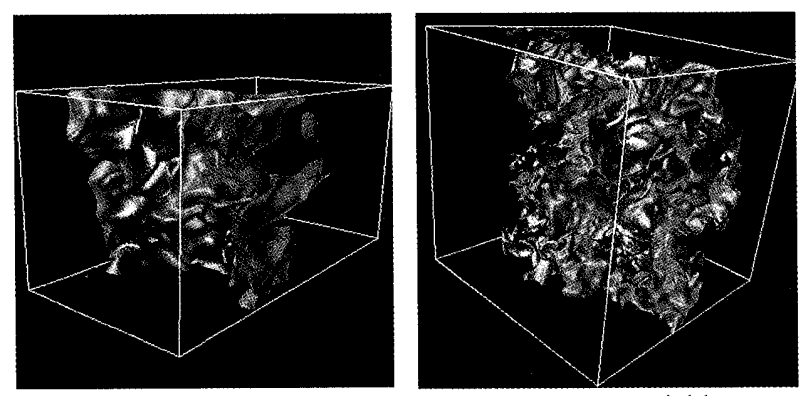

Fig. 1 Contour surfaces of reaction progress variable $c=$ 0.30 for planar turbulent premixed flame (right: $R e_{\lambda}=60.8$ and left: $R e_{\lambda}=97.1$ ). 


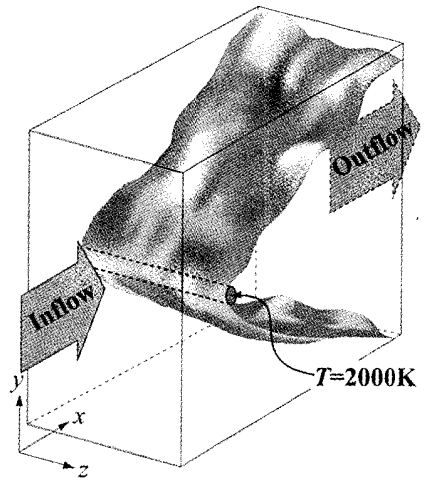

Fig. 2 Schematic of the flow geometry for DNS of turbulent V-flame.

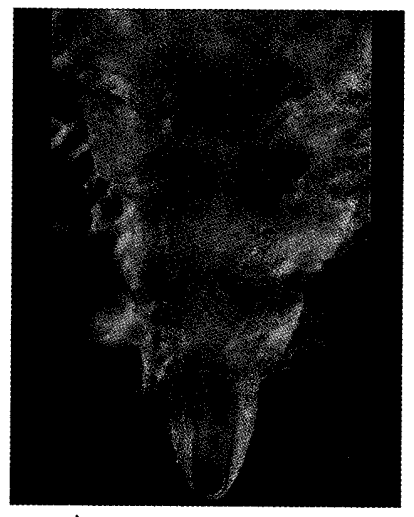

Fig. 3 Volume rendering of reaction progress variable of turbulent $\mathrm{V}$-flame for $R e_{\lambda}=60.8$ (view from $z$ direction).

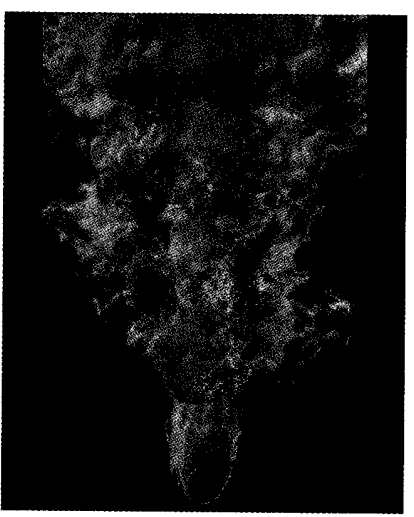

Fig. 4 Volume rendering of reaction progress variable of turbulent $\mathrm{V}$-flame for $R e_{\lambda}=97.1$ (view from $z$ direction).
常な時刻におけるボリュームレンダリングによる反忘進行 変数の分布を $\mathrm{V}$ 型火炎の場合について示している。これら の結果は Reynolds 数と対流速度の違いによる火炎構造の 相違を示しており，その特徴の一部は同じReynolds 数の平 面乱流火炎でも観察される。

\section{3. 火炎面近傍での歪み速度}

火炎面付近での歪み速度特性検証するために歪夕速度 テンソルから主歪み速度を算出した。図 5 は平面乱流火炎

$\left(R e_{\lambda}=60.8\right.$ 及び 97.1) と $\mathrm{V}$ 型乱流火炎 $\left(R e_{\lambda}=60.8\right)$ で $c=0.20$ における主歪み速度の PDFを比較したものである.ここで, $\alpha ， \beta$ 及び $\gamma$ はそれぞれ最大，中間及び最小主歪み速度であ り。それぞれの主歪み速度は Kolmogorov length scale と Kolmogorov velocity scale で正規化されている。また，本研 究では火炎面を定義するために，未燃予混合気温度及び既 燃ガス温度で定義される反応進行変数を導入した。図 5 で 示されるPDF は, 膨張, ReynoIds 数及び対流による効果を 明確に示している. Reynolds 数が異なる 2 つの平面乱流火 炎の PDF を比較すると, Reynolds 数の增加とともに，主歪 み速度の確率密度の分散が大きくなることがわかる。これ は, $R e_{\lambda}=97.1$ の場合では $R e_{\lambda}=60.8$ に比べて乱流運動による 歪办効果が顕著であることを示している， $R e_{\lambda}=60.8$ の平面 火炎と V 型火炎の結果を比較すると, PDF に大きな違いが 観察される。V 型火炎ではより分散が大きくなっており, 乱流運動による歪みがより顕著な影響を及ぼしている。さ らに, 同じ反応進行変数においても PDF がピークを示す值 が異なり，V型火炎では平面火炎に比べて歪みテンソルの 固有值の中間值 $\beta$ が 0 近傍に位置し，より 2 次元的な特性 を示している. また， $\alpha$ と坊 PDFがピークを示す值の絶 対值はV 型火炎ではより増大している。これらは保炎用口 ッド後方の伴流と火炎面が平均速度の方向と平均的に角度 を有するためであると考えられる。すなわち, 同じ Reynolds 数の乱流燃焼場であっても平均的な火炎面之平均流の幾何 学的関係及び平均流の強さによって火炎面に作用する歪み 速度の特性が変化すると考えられる。

乱流と火炎面の干渉機構の特性は主歪夕速度と火炎面の 配向特性に現われる。そこで，本研究ではこの干涉機構を 解明するために歪子速度テンソルの固有ベクトルと火炎面 の法線方向の配向特性についても検討した。炏面法線方 向と主歪みベクトルの内角の PDF を検討した結果，高 Reynolds 数乱流火炎では火炎面法線方向は歪みテンソルの 最少固有值の固有べクトルと平行になる傾向を持つことが

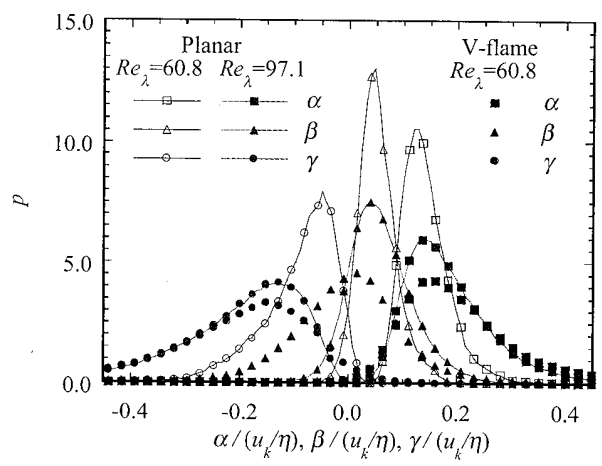

Fig. 5 PDF of the eigen value of strain rate tensor near the flame $(c=0.20)$ for statistically planar turbulent premixed flame $\left(R e_{\lambda}=60.8\right.$ and $\left.R e_{\lambda}=97.1\right)$ and turbulent $\mathrm{V}$-flame $\left(R e_{\lambda}=60.8\right)$.

分かった. これは高 Reynolds 数乱流火炎では乱流運動に よる歪み速度が燃焼による膨張効果に比べてより支配的で あるためと考えられる。

4. まとめ

本研究では, 詳細化学反応機構を考慮に入れた三次元 DNS を統計的に平面な水素・空気乱流予混合火炎と V 型水 素・空気乱流子混合火炎に対して，それぞれ異なる2つの Reynolds 数について行い, 歪み速度特性及び主歪み速度と 火炎面の配向特性を検討した。その結果，平均的な火炎面 と平均流の幾何学的関係及び平均流の強さによって火炎面 に作用する歪み速度の特性が変化することが示された。さ らに, Reynolds 数が高くなるほど最大圧縮に対応する歪み 速度と火炎面の配向は強くなることが分かった。

\section{謝辞}

本研究の一部は科学研究費補助金若手研究(S) (No.2067 6004)により行われたものであり，ここに記して謝意を表す.

\section{参考文献}

(1) Tanahashi, M. et al., Proc. Combust. Inst. 30 (2005), 1665.

(2) Shepherd, I. G. Proc. Combust. Inst., 26 (1996), 373.

(3) Hartung, G. et al., Phys. Fluids, 20 (2008), 035110.

(4) Tanahashi, M. et al., Proc. Combust. Inst., 29 (2002), 2041.

(5) Nada, Y. et al. Proc. 5th Asia-Pacific Conf. Combust., (2005) 429

(6) Tanahashi, M. et al., Proc. of 11 th Symp. on Turbulent Shear Flow 1, (1997), 4. 